This document is the accepted manuscript version of the following article: Pesce, S., Campiche, S., Casado-Martinez, C., Ahmed, A. M., Bonnineau, C., Dabrin, A., ... Ferrari, B. J. D. (2020). Towards simple tools to assess functional effects of contaminants on natural microbial and invertebrate sediment communities. Environmental Science and Pollution Research, 27, 6680-6689. https://doi .org/10.1007/s11356-019-07331-z

\title{
Towards simple tools to assess functional effects of contaminants on natural microbial and invertebrate sediment communities
}

\author{
Stéphane PESCE ${ }^{a}$, Sophie CAMPICHE ${ }^{b, c}$, Carmen CASADO-MARTINEZ ${ }^{b}$, Ayanleh MAHAMOUd \\ AHMEd ${ }^{a, d}$, Chloé BonnineAu ${ }^{a}$, Aymeric DABrina ${ }^{a}$, Emilie LYAUTEY ${ }^{d}$, Benoît J.D. FerRARI ${ }^{b}$
}

\author{
a. INRAE, UR RiverLy, 69625 Villeurbanne, France \\ b. Swiss Centre for Applied Ecotoxicology, Ecotox Centre, EPFL-ENAC-IIE-GE, Station 2, 1015, Lausanne, \\ Switzerland \\ C. EnviBioSoil, Chemin de l'Ochettaz 12, 1025, Saint-Sulpice, Switzerland \\ d. Université Savoie Mont Blanc, INRAE, CARRTEL, 74200, Thonon-les-Bains, France \\ * stephane.pesce@inrae.fr
}

Received: 14 June 2019 /Accepted: 6 December 2019 /Published online: 20 December 2019

\# Springer-Verlag GmbH Germany, part of Springer Nature 2019

\begin{abstract}
Surface sediments can accumulate contaminants that affect microorganisms and invertebrates and disturb benthic ecological functions. However, effects of contaminants on ecological functions supported by sediment communities are understudied. Here, we tested the relevance of two simple tools to assess the ecotoxicological effects of metal contamination on natural sediment communities using particulate organic matter breakdown and decomposition as a functional descriptor. To this aim, we performed a 21-day laboratory microcosm experiment to assess the individual and combined effects of $\mathrm{Cu}$ and As (nominal concentration of $40 \mathrm{mg} \mathrm{kg}-1 \mathrm{dw}$ each) using the bait-lamina method (cellulose, bran flakes, and active coal in PVC strips) as well as artificial tablets (cellulose, bran flakes and active coal embedded in an agar matrix). Sediment toxicity was also evaluated using the standardized ostracod toxicity test. Both the bait-lamina and artificial tablet methods showed low effects of As on organic matter breakdown and decomposition but strong effects of $\mathrm{Cu}$ on this important ecological function. Both also showed that the presence of $\mathrm{Cu}$ and As in mixture in the sediment induced total inhibition of organic matter breakdown and decomposition. The ostracod toxicity test also showed high toxicity of Cu-spiked and Cu-plus-As-spiked sediments and low toxicity of As-spiked sediments. Besides confirming that artificial organic matter substrates are relevant and useful for assessing the functional effects of contaminants on sediment micro- and macro-organism communities, these results suggest that the proposed methods offer promising perspectives for developing tools for use in assessing functional ecotoxicology in the sediment compartment.
\end{abstract}

\section{Keywords}

Bait-lamina test, Functional ecotoxicology, Invertebrates, Metals, Microbial communities, Organic matter 


\section{Introduction}

In river ecosystems, sediment is a habitat that supports large biological diversity (from viruses to fish) as well as a functional compartment that plays a major role in biogeochemical cycles (Zoppini and Marxsen, 2011). However, with increasing nutrients, metals, and persistent organic pollutants released into human-dominated watersheds, a large amount of sediments accumulate various contaminants along the river continuum, particularly those exhibiting a strong affinity for particulate matter (Burton, 2013). Significant deposition of such contaminants can represent a risk for benthic communities and disrupt the functioning of aquatic ecosystems. It is therefore crucial to evaluate sediment ecotoxicological quality. This can best be achieved by means of integrated laboratory- and field-based approaches (i.e., weight-of-evidence studies) combining not only exposure-based tools but also effectbased metrics at different levels of biological organization (e.g., Chapman, 1990; Vignati et al., 2007). However, despite a number of ecotoxicological approaches available for evaluating sediment quality, there is a limited number of tools developed at community level (Höss et al., 2011; De Castro-Català et al., 2016; Pesce et al., 2018). Accordingly, sediment ecotoxicological studies performed at community level are still scarce in comparison with those concerning the soil and water compartments. Indeed, while the ecological role of sediment communities is widely recognized, there are still big gaps in knowledge on the direct and indirect effects of contaminants on their ecological traits and functions and on the resulting consequences for aquatic ecosystem functioning (Gardham et al., 2015; Mahamoud Ahmed et al., 2018).

Besides the need for further knowledge on the potential toxicity of contaminants on ecological functions and processes performed by benthic communities, a major challenge in environmental risk assessment of sediment pollution still lies in establishing a causal relationship between field exposure and functional effects at benthic community level (Faupel et al., 2012; Pesce et al., 2018). The need for indicators of ecotoxicological impacts on ecosystem functioning has driven a surge of interest into the use of natural or artificial organic substrate breakdown and decomposition to assess the functional integrity of contaminated aquatic (Young et al., 2008; Piscart et al., 2011; Brosed et al., 2016) and terrestrial ecosystems (Filzek et al., 2004; Niemeyer et al., 2012). In sediment, the decomposition and consumption of organic matter by microbial and invertebrate benthic communities can be measured via several methods, such as using buried leaf litter bags (Piscart et al., 2011) or buried artificial substrates like the DECOTAB tablet consisting of cellulose powder embedded in an agar matrix (Kampfraath et al., 2012). In soil ecosystems, the use of the standardized bait-lamina test (ISO 18311, 2016) as a functional indicator of soil ecological integrity and/or as a tool for ecological risk assessment of soil contamination (ISO 19204, 2017) is now a well-established method (Griffiths et al., 2016; Welsch et al., 2019). Beyond their valuable ecological relevance, these methods measuring global organic matter loss have the advantages of being relatively inexpensive and easy to use, and thus offer useful perspectives for routine ecotoxicological monitoring. The potential effects of contaminants on the capacity of benthic communities to degrade particulate organic matter in sediments has been poorly studied. Using mesocosm studies and testing realistic (i.e., several dozen $\mathrm{mg} / \mathrm{kg}$ ) to very high (i.e., several hundred $\mathrm{mg} / \mathrm{kg}$ ) exposure scenarios, Gardham et al. (2015) and Sutcliffe et al. (2019) observed no chronic effect of copper sediment contamination on the decomposition of leaf litters, cotton strips, and/or cellulose papers deployed on the surface of sediments and/or buried 1-2 $\mathrm{cm}$ below this surface. Piscart et al. (2011) also showed a lack of effect of agricultural contamination (pesticides and metals, including copper) on the decomposition of leaf litters buried $20 \mathrm{~cm}$ below the sediment surface in two French rivers. However, the potential toxicity of environmental concentrations of copper on the diversity of natural benthic microbial communities and on their capacity to perform several functions 
has been recently demonstrated (Mahamoud Ahmed et al., 2018; Sutcliffe et al., 2018, 2019). There is therefore a need for studies to evaluate the sensitivity of different methods assessing particulate organic matter breakdown and decomposition to detect the effects of environmental contaminant exposure on this important ecological function in the sediment compartment.

To this aim, we performed a 21-day laboratory microcosm experiment using two different kinds of artificial organic matter substrate containing cellulose powder, bran flakes, and active coal: one enclosed in a PVC strip (i.e., adapted from the bait-lamina method used for soil) and one encapsulated in agar (i.e., artificial tablet). These two different tools are easy to deploy in the field and are easy to interpret using respectively a visual analysis procedure (bait-laminas) and a weight loss measurement (tablets).

Given their frequent occurrence in many river sediments (e.g., Farag et al., 2007; Kohušová et al., 2011), copper ( $\mathrm{Cu}$ ) and arsenic (As) were chosen as model contaminants. It has been shown that $\mathrm{Cu}$ and As can reach concentrations up to several hundred $\mathrm{mg} \mathrm{kg-1} \mathrm{dw}$ in sediments collected in contaminated rivers (Farag et al., 1998, 2007; Ancion et al., 2013), thus posing an ecotoxicological risk for benthic organisms (MacDonald et al., 2000). Here, we assessed the individual and combined effects of $\mathrm{Cu}$ and As on the capacity of previously unexposed natural sediment communities to consume and decompose particulate organic matter. We considered a worst-case but realistic exposure scenario by choosing a theoretical nominal concentration of $40 \mathrm{mg} \mathrm{kg}-1 \mathrm{dw}$ for each metal. These concentrations are respectively representative of high (i.e., 3rd quartile) and very high (i.e., 9th decile) levels of sediment contamination with $\mathrm{Cu}$ and $\mathrm{As}$ in French aquatic ecosystems (INERIS, 2010; DREAL-REMIPP, 2013). The toxicity of the sediment following $\mathrm{Cu}$ and/or As treatment was also assessed using the standardized ostracod toxicity test (ISO 14371, 2012). This study allowed us to evaluate the usefulness of assessing particulate organic matter loss (i.e., consumption of organic matter through breakdown and decomposition activities) as a functional ecotoxicological endpoint, and to discuss the relevance of the two kinds of artificial organic matter substrates tested for developing functional ecotoxicological studies at community level in the sediment compartment.

\section{Materials and methods}

\section{Sediment sampling and spiking with metals}

About $100 \mathrm{~L}$ of surface sediments $(0-10 \mathrm{~cm})$ were collected in June 2016 at the "Pont de Chazey" sampling station (latitude $45^{\circ} 54^{\prime} 38^{\prime \prime} \mathrm{N}$-longitude $5^{\circ} 14^{\prime} 11^{\prime \prime} \mathrm{E}$ ) on the Ain river, which is one of the main tributaries of the Upper Rhône River (upstream of the city of Lyon) in France. This station was chosen as reference station as it presents a low level of metal contamination (Dabrin et al., 2012). Immediately after sampling, the sediment was sieved at $2 \mathrm{~mm}$ to eliminate debris and coarse particles and to remove large macrobenthic organisms. The sieved sediment, containing $<2 \mathrm{~mm}$ natural communities (i.e., microorganisms, meiofauna, and small macrofauna) was homogenized and stored at $4{ }^{\circ} \mathrm{C}$ overnight until spiking. Aliquots of $13 \mathrm{~kg}$ (wet weight) of sediment were spiked or not with copper (Cu) and/or arsenic (As), at a targeted nominal concentration of $40 \mathrm{mg} \mathrm{kg}-1 \mathrm{dw}$ for each metal, using a protocol slightly modified from Dabrin et al. (2012) after preliminary spiking tests and according to the sediment characteristics (i.e., $70 \%$ of $250-300 \mu \mathrm{m}$ particles, $18 \%$ of $70-80 \mu \mathrm{m}$ particles, $2 \%$ of 10-20 $\mu \mathrm{m}$ particles, $<1 \%$ clays, and $8 \%$ silts). Further details on the spiking procedure can be found in Mahamoud Ahmed et al. (2018). 


\section{Experimental design and microcosm setup}

The experiment was performed in 13 glass indoor channels (length $\times$ width $\times$ height $=83 \mathrm{~cm} \times 11$ $\mathrm{cm} \times 10 \mathrm{~cm}$; Fig. $1 \mathrm{a}$ and b) containing $3.5 \mathrm{~kg}$ wet weight of previously spiked sediment (equivalent to about a 3-cm-thick sediment) and a $6 \mathrm{~L}$ mixture of demineralized water and uncontaminated drilled groundwater (75:25). Each channel was connected to a 20-L glass tank (i.e., one independent tank per channel) through an aquarium pump (NEWA MJ 750) delivering water recirculation at a flow velocity of $1.5 \mathrm{~L} \mathrm{~min}-1$. The microcosm experiment was conducted for 21 days (with weekly surface water renewals) under ambient laboratory temperature conditions (about $21^{\circ} \mathrm{C}$ ) and following a 13:11-h light/dark cycle. This exposure duration is in line with the recommendations formulated in the baitlamina ISO protocol, which stipulates that the bait lamina exposure time in soil lasts on average 10 to 20 days in temperate zones (ISO 18311, 2016).

Four experimental conditions were tested, i.e., (i) "Ref," (ii) "Cu," (ii) "As," (iv) "Mix," using three independent replicate channels filled at day 0 with the sediment previously spiked with (i) uncontaminated water, (ii) $\mathrm{Cu}$ (nominal concentration of $40 \mathrm{mg} \mathrm{kg}-1 \mathrm{dw}$ ), (iii) As (nominal concentration of $40 \mathrm{mg} \mathrm{kg-1} \mathrm{dw),} \mathrm{and} \mathrm{(iv)} \mathrm{a} \mathrm{mixture} \mathrm{of} \mathrm{Cu}$ and As (nominal concentration of $40 \mathrm{mg}$ $\mathrm{kg}-1 \mathrm{dw}$ for each metal), respectively. Furthermore, the remaining channel, which served as a sterile control microcosm (i.e., "Sterile"), was filled with the sediment previously spiked with uncontaminated water and further autoclaved at $120^{\circ} \mathrm{C}$ for $1 \mathrm{~h}$.

\section{Metal analysis in sediments and water}

$\mathrm{Cu}$ and As concentrations in sediment were checked just after the spiking procedure (day $0, \mathrm{~d} 0$ ) and at the end of the experiment (d21). Accordingly, composite samples of sediment were collected after spiking ( $d 0$, one replicate per spiking condition) and in each channel ( $d 21$, three replicates per experimental condition) and stored in polypropylene tubes. After drying in an oven at $40{ }^{\circ} \mathrm{C}$, the sediments were grinded and homogenized with an agate ball mill (PM100, Retsch) and then kept dry in a desiccator. Approximately $300 \mathrm{mg}$ of crushed and homogenized sediment was then mineralized with aqua regia ( $2 \mathrm{~mL} \mathrm{HNO} 3$ and $6 \mathrm{~mL} \mathrm{HCl} \mathrm{SUPRAPUR} \mathrm{quality)} \mathrm{in} \mathrm{a} \mathrm{microwave} \mathrm{digester} \mathrm{(MARS-} 6$ from CEM) using teflon reactors $\left(T^{\circ}: 180^{\circ} \mathrm{C}\right.$ for $15 \mathrm{~min}$ ). After mineralization, the samples were diluted in ultrapure water (Veolia) to obtain a volume of $50 \mathrm{~mL}$. $\mathrm{Cu}$ and As concentrations in the sediment samples were measured by inductively coupled optical emission spectrometry (ICP-OES 720 ES, series 700, Agilent) according to AFNOR NF EN ISO 11885. The water content was measured in order to correct the results if necessary. The quantification limits were $0.66 \mathrm{mg} \mathrm{kg}-1 \mathrm{dw}$ for $\mathrm{Cu}$ and $1.6 \mathrm{mg} \mathrm{kg-1}$ dw for As.

Metal concentrations in the overlying water samples were measured at d0 (within the first $2 \mathrm{~h}$ after the installation of the artificial channels), d7, d14 (before water renewals), and d21. Samples $(30 \mathrm{~mL})$ were filtered using a polypropylene syringe and a cellulose acetate filter $(0.45 \mu \mathrm{m}$ porosity and $30 \mathrm{~mm}$ diameter). The filtered water was collected into polypropylene tubes, acidified with $0.5 \%$ (vol/vol) HNO3 (65\%, Suprapur, Merck), and placed in the dark at $4{ }^{\circ} \mathrm{C}$ until analysis. $\mathrm{Cu}$ and As concentrations were measured by inductively coupled plasma mass spectrometry (ICP-MS, X7, Thermo Electron Series II) according to AFNOR NF EN ISO 17294.2. The quantification limits were $0.05 \mu \mathrm{g} L-1$ for $\mathrm{Cu}$ and 0.01 $\mu \mathrm{g} L-1$ for As. 


\section{Ostracod test}

The sediment toxicity test using the ostracod Heterocypris incongruens was performed using the commercial kit available from MicroBioTests and in accordance with the corresponding ISO standard 14,371 (ISO 2012). Briefly, $56 \mathrm{~h}$ before the start of the tests, ostracod cysts were incubated in standard freshwater at $25{ }^{\circ} \mathrm{C}$ under continuous illumination. After $48 \mathrm{~h}$ of incubation, the neonates were prefed with algal food (Spirulina) and incubated for 4 more hours. Each well of the microplate was filled with $2 \mathrm{~mL}$ of standard freshwater and $1 \mathrm{~mL}$ of sediment. Then, $2 \mathrm{~mL}$ of algal food, Scenedesmus spp., was added as extra food during testing to prevent starvation and its possible influences on ostracod growth or mortality. Then, 10 freshly hatched ostracods were transferred from the hatching Petri dish to each well. Each test sediment and each control was tested in six replicates. The microplates were incubated at $25^{\circ} \mathrm{C}$ for 6 days in darkness in a humidity chamber. On d0, the length of 10 neonates was measured using CellD microscope software (Olympus). At the end of the exposure period, the ostracods were recovered from the microplates and transferred to a glass slide for counting and length measurement. Length at the end of the 6-day exposure was converted to growth (difference between length at the end and at the start of exposure) and to relative values with respect to the control sediment (\% control response).

Sediments were tested for toxicity on $\mathrm{d} 0$ and $\mathrm{d} 21$. Only one sediment was tested on $\mathrm{d} 0$, corresponding to a sample collected after spiking, whereas one composite sample per replicate was collected and tested on $\mathrm{d} 21$. The clean sand provided with the commercial kit was used as control sediment in all trials.

\section{Organic matter loss}

The functional effects of metal contamination were assessed on the natural benthic communities present in the sieved sediments (i.e., microorganisms and macro-invertebrates $<2 \mathrm{~mm}$ ) by studying the consumption of particulate organic matter (i.e., organic matter breakdown and decomposition) using (i) the bait-lamina method (ISO 18311, 2016) adapted to the sediment compartment and (ii) artificial tablets modified from the DECOTABs model (Kampfraath et al., 2012).

The bait-lamina material (Von Törne, 1990; Kratz, 1998) consisted of PVC plastic strips of $160 \times 6 \times 1$ $\mathrm{mm}$ perforated with 16 holes at 5-mm intervals (Fig. 1c). The strips were purchased from Terra Protecta ${ }^{\circledR} \mathrm{GmbH}$. Stick holes were filled with a standard mix made of cellulose powder (Fluka 11363), bran flakes (ground down and sieved to $<500 \mu \mathrm{m}$ ), and active coal (Merck 1.02186) (70:27:3 w/w) following the Terra Protecta protocol (www.terra-protecta.de). The principle of the test consists in exposing the bait-lamina in the sediment and assessing the loss of bait material consumed by the organisms (percentage of emptied apertures in comparison to the total number of holes after retrieval). In each replicate, 5 bait-lamina strips were distributed over the entire length of the channel. They were buried horizontally about $1 \mathrm{~cm}$ below the sediment surface (instead of vertically for soil; see ISO 18311) and exposed for 21 days. At the end of the experiment, the strips were removed, then examined by eye under bright light conditions, and the number of pierced holes was recorded. Bait holes were categorized into three classes, i.e., not pierced (scored 0), partially pierced (scored 1; light passing through a portion of the bait) or totally pierced (scored 2). Organic matter loss was expressed as a percentage of perforated holes for the 5 bait-lamina per channel.

The artificial tablets (Fig. 1d) were made using a protocol inspired from Kampfraath et al. (2012). Purified agar ( $3 \mathrm{~g}$, agar-agar Merck 1.01614) was dissolved in $150 \mathrm{~mL}$ of demineralized water at $100^{\circ} \mathrm{C}$ for a few minutes. After cooling to about $50^{\circ} \mathrm{C}, 9 \mathrm{~g}$ of cellulose powder (Fluka 11363), $3 \mathrm{~g}$ of pre-ground bran, and $0.4 \mathrm{~g}$ of active coal (Merck 1.02186) was added to the suspension, which was poured into a multiwell polycarbonate mold ( $20 \mathrm{~mm}$ diameter, $5 \mathrm{~mm}$ height) to cast tablets with a final volume of 
about $1885 \mathrm{~mm} 3$. After solidification of the agar, the tablets were dried for $48 \mathrm{~h}$ at $70{ }^{\circ} \mathrm{C}$ before being weighed with an analytical balance (Sartorius A200S). Mean dry mass of the 65 tablets used in the microcosm experiment was $213.99 \pm 9.32 \mathrm{mg}$. Each tablet was covered with an individual $5 \mathrm{~mm}$ meshsize plastic net, and 5 tablets were buried about $1 \mathrm{~cm}$ below the sediment surface in each channel. At the end of each experiment, the tablets were removed, dried at $70^{\circ} \mathrm{C}$ for at least 3 days, and weighed. Changes in dry mass (DM) were expressed as \% mass remaining relative to initial DM (measured individually for each tablet at the start of the experiment). The loss of DM in the sterile microcosm was used as a control to estimate the abiotic degradation of the tablets under the tested experimental conditions. This control was not needed for bait-lamina as we had previously checked the absence of abiotic degradation after several weeks in similar microcosms (unpublished data).

Organic matter loss measured both by the bait-lamina test and the use of artificial tablets and expressed in percentages were transformed as asin (squareroot $(x / 100)$ prior to statistical analyses to meet the assumptions of normality and homoscedasticity. Significant differences between treatment were detected by one-way analysis of variance (ANOVA) followed by a Tukey test (Yandell, 1997), where a $\mathrm{p}$ value $<0.05$ was considered to indicate a significant difference between treatments.

Fig. 1. Pictures of the indoor microcosms (a and b) and selected illustrations (from other experiments) of the bait lamina (c, freshly retrieved in situ from river surface sediments and covered by oligochetes) and tablet (d) tools..
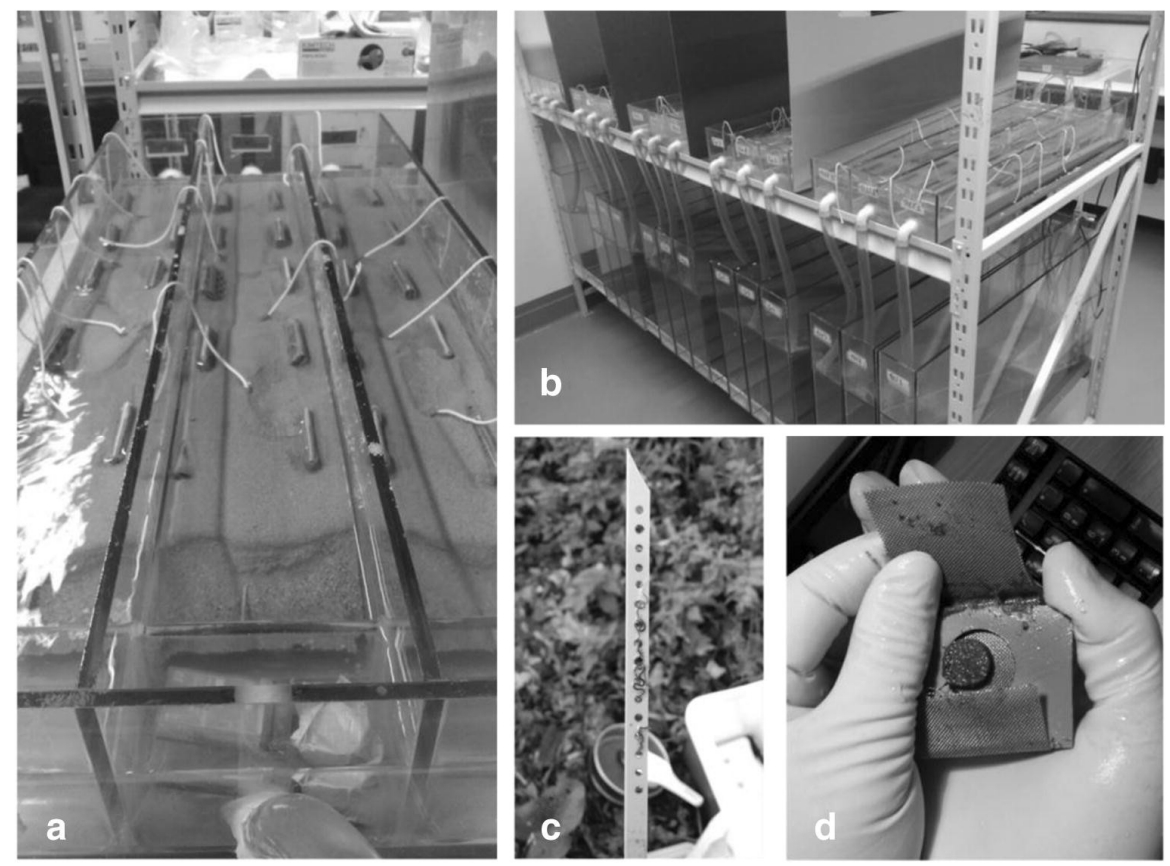

\section{Results and discussion}

\section{Sediment metal concentrations and ecotoxicity}

Sediment samples containing natural communities were collected in a section of river known to be relatively uncontaminated by metals. This was confirmed by the chemical analysis (Table 1) which showed initial concentrations of As comprised between 2.8 and $3.3 \mathrm{mg} \mathrm{kg}-1 \mathrm{dw}$ and concentrations of $\mathrm{Cu}$ close to $1.8 \mathrm{mg} \mathrm{kg}-1 \mathrm{dw}$. Measured As and $\mathrm{Cu}$ concentrations in the natural sediment used were thus respectively bracketed in the low (i.e., 1st quartile) and very low (i.e., 1st decile) sediment contamination levels in French aquatic ecosystems (INERIS, 2010). Moreover, the ostracod toxicity test showed no initial toxicity of the natural sediment, with mortality (Table 1) and growth (results not shown) in the range of that observed for control sediments (less than $20 \%$ mortality and negative growth inhibition percentages with respect to controls, ISO 14371). These findings attest that the studied communities were not previously exposed to high As and Cu concentrations, ensuring that the component invertebrates (Posthuma and van Straalen, 1993; Clements, 1999) and microorganisms (Tlili et al., 2011) were not preadapted to As and Cu metals, thus justifying the use of natural sediment from the Ain River as reference in the present experiment. 
Table 1. Concentrations of $\mathrm{As}$ and $\mathrm{Cu}(\mathrm{mg} \mathrm{kg}-1 \mathrm{dw}$ ) in sediments after spiking (day $0, \mathrm{n}=1$ ) and after 21 days (mean $\pm S D, n=3$ ) in the four treatments, and resulting toxicity to ostracods (control-normalized mortality percentage). Toxicity results on day 0 are averages of 6 replicates per sample, with one single sediment sample per treatment. Results on day 21 are means \pm SD of 3 sediment samples per treatment ( 6 replicates per sample).

\begin{tabular}{|c|c|c|c|c|c|c|}
\hline \multirow[t]{3}{*}{ Treatment } & \multicolumn{3}{|c|}{ Day 0 (after spiking) } & \multicolumn{3}{|l|}{ Day 21} \\
\hline & As & $\mathrm{Cu}$ & Ostracod mortality & As & $\mathrm{Cu}$ & Ostracod mortality \\
\hline & $\left(\mathrm{mg} \mathrm{kg} \mathrm{dw}^{-1}\right)$ & $\left(\mathrm{mg} \mathrm{kg} \mathrm{dw}{ }^{-1}\right)$ & (\%) & $\left(\mathrm{mg} \mathrm{kg} \mathrm{dw}{ }^{-1}\right)$ & $\left(\mathbf{m g ~ k g ~ d w ^ { - 1 } )}\right.$ & (\%) \\
\hline $\mathrm{Cu}$ & 3.24 & 56.56 & 100.0 & $2.96 \pm 0.13$ & $43.60 \pm 2.60$ & 100.0 \\
\hline As & 31.33 & 1.75 & 16.6 & $26.20 \pm 1.20$ & $2.60 \pm 1.20$ & $2.0 \pm 5.0$ \\
\hline
\end{tabular}

After spiking, As (31.2-31.3 mg kg-1 dw) and $\mathrm{Cu}$ (55.1-56.6 mg kg-1 dw) concentrations were respectively lower and higher than the target concentrations (40 mg kg-1 dw), without notable difference between individual and combined spiking for each metal. At the end of the experiment, there was still no significant difference in measured concentrations between individual and combined treatments for both As and $\mathrm{Cu}$ concentrations. However, the in-sediment concentrations of both metals decreased over the 21 days, with mean values ranging between $26.2 \mathrm{mg} \mathrm{kg}-1 \mathrm{dw}$ and $24.6 \mathrm{mg}$ $\mathrm{kg}-1 \mathrm{dw}$ for As and $43.6 \mathrm{mg} \mathrm{kg}-1 \mathrm{dw}$ and $47.8 \mathrm{mg} \mathrm{kg}-1 \mathrm{dw}$ for $\mathrm{Cu}$ at the end of the experiment. Both the sediment spiked with $\mathrm{Cu}$ and the sediment spiked with the mixture of $\mathrm{Cu}$ and As caused $100 \%$ mortality of ostracods on $\mathrm{d} 0$ and $\mathrm{d} 21$. The mortality rate observed in Cu-contaminated sediments (alone or combined with As) was very high compared to the study of Torokne and Toro (2010), who observed less than $60 \%$ mortality in natural sediments containing up to $273 \mathrm{mg} \mathrm{Cu} \mathrm{kg-1}$ in mixture with other contaminants. Our results thus point to a very high bioavailability of $\mathrm{Cu}$, probably linked to a high level of $\mathrm{Cu}$ release from the spiked sediment under our experimental conditions. However, this hypothesis is only partially supported by the chemical analyses performed weekly in the overlying water samples, which showed that dissolved Cu concentrations fluctuated between 38.9 and $60.1 \mu \mathrm{g}$ L-1 over the course of the experiment (Table 2). In comparison, Sevilla et al. (2014) observed $100 \%$ mortality of $\mathrm{H}$. incongruens ostracods exposed for 6 days to dissolved $\mathrm{Cu}$ concentrations from 260 up to $2600 \mu \mathrm{g} \mathrm{L-1,} \mathrm{and} \mathrm{Kudlak} \mathrm{et} \mathrm{al.} \mathrm{(2011)} \mathrm{found} \mathrm{a} \mathrm{median} \mathrm{lethal} \mathrm{concentration} \mathrm{(LC50,} 6$ days) of $953 \mu \mathrm{g}$ Cu L-1.

Table 2. Concentrations (means $\pm S D, n=3$ ) of $C u$ and $A s$ in the overlying water $(\mu g \mathrm{~L}-1)$ at do (within the first $2 \mathrm{~h}$ after the installation of the artificial channels), d7, d14 (before water renewals), and d21 in the four treatments.

\begin{tabular}{|c|c|c|c|c|c|c|c|c|}
\hline \multirow[b]{2}{*}{ Treatment } & \multicolumn{2}{|l|}{ Day 0} & \multicolumn{2}{|l|}{ Day 7} & \multicolumn{2}{|l|}{ Day 14} & \multicolumn{2}{|l|}{ Day 21} \\
\hline & As $\left(\mu \mathrm{g} \mathrm{L}^{-1}\right)$ & $\mathrm{Cu}\left(\mu \mathrm{g} \mathrm{L}^{-1}\right)$ & As $\left(\mu g L^{-1}\right)$ & $\mathrm{Cu}\left(\mu \mathrm{g} \mathrm{L}^{-1}\right)$ & As $\left(\mu \mathrm{g} \mathrm{L}^{-1}\right)$ & $\mathrm{Cu}\left(\mu \mathrm{g} \mathrm{L}^{-1}\right)$ & As $\left(\mu \mathrm{g} \mathrm{L}^{-1}\right)$ & $\mathrm{Cu}\left(\mu \mathrm{g} \mathrm{L}^{-1}\right)$ \\
\hline Ref & $0.6 \pm 0.1$ & $1.4 \pm 0.6$ & $1.4 \pm 0.1$ & $1.5 \pm 0.1$ & $1.0 \pm 0.2$ & $1.9 \pm 1.0$ & $0.8 \pm 0.1$ & $2.3 \pm 1.2$ \\
\hline As & $759.4 \pm 51.0$ & $1.3 \pm 0.2$ & $2829.3 \pm 126.1$ & $1.7 \pm 0.0$ & $1455.3 \pm 58.0$ & $4.9 \pm 5.7$ & $863.4 \pm 80.3$ & $5.0 \pm 3.3$ \\
\hline Mix & $798.4 \pm 49.6$ & $69.0 \pm 3.2$ & $2339.7 \pm 107.8$ & $59.9 \pm 2.4$ & $1533.3 \pm 110.8$ & $50.4 \pm 2.0$ & $901.8 \pm 61.2$ & $41.4 \pm 0.8$ \\
\hline
\end{tabular}

The As-spiked sediment initially showed intermediate levels of toxicity with $16.6 \%$ mortality and $28.3 \%$ growth inhibition on day 0 . Toxicity decreased over time, and by d21 there was no growth inhibition and the mortality percentages were very low $(2 \pm 5 \%$, no significant difference from the reference sediment). It suggests a lack of toxicity of As under our experimental conditions despite very strong As release from the sediments based on the dissolved As concentrations measured throughout the study (i.e., 760 to $2829 \mu \mathrm{g} L-1$, Table 2). The results are consistent with Kudlak et al. (2011) who showed that dissolved arsenic (spiked as As203) was the least toxic among many metals tested (including $\mathrm{Cu}, \mathrm{Hg}$, Cd) using this same ostracod testing protocol and species. 
Relevance of artificial organic matter substrates for assessing the functional effects of As and Cu in the tested conditions

The main aim of this study was to test the relevance of two methods for assessing ecotoxicological effects on the consumption of particulate organic matter by benthic communities in contaminated sediments. To this aim, two kinds of artificial substrates containing cellulose powder, bran flakes and active coal were used-one enclosed in a PVC strip (i.e., bait-lamina method), and the other encapsulated in agar (i.e., artificial tablet). The bait-lamina method was first introduced by Von Törne (1990) to assess the consumption of organic matter in soils. Its use in soil ecology is now wellestablished and standardized, and the method was recently proposed as a relevant and cost-effective tool that should be included in a set of indicators for European monitoring of soil ecosystem functions (Griffiths et al., 2016). Several studies have also evidenced that bait-lamina can serve as a tool to assess the effects of contaminants, including metals and pesticides, in the organic matter consumption activity of soil communities (Filzek et al., 2004; Andre et al., 2009; Niemeyer et al., 2018). Along these lines, Bart et al. (2018) proposed the use of bait-lamina to perform ecotoxicological laboratory tests on the feeding activity of soil enchytraeidae. Because of its simplicity, its applicability in both microcosm or field studies, and the fact that organic matter breakdown is one of the most integrative processes in soil ecosystems, the bait-lamina method was identified as an appropriate tool for refined screening (tier II) for soil environmental risk assessment (ERA) (ISO 19204, 2017; Jensen and Mesman, 2006; Casabe et al., 2007). Given the importance of microorganisms and invertebrates in organic matter breakdown in both soil compartment and sediment compartment, the bait-lamina may be equally suitable for sediment ERA. However, to the best of our knowledge, the applicability of the baitlamina in sediments has not yet been demonstrated.

In the present study, bait-lamina organic matter loss in the reference sediment without metal spiking reached $33.5 \pm 8.1 \%$ after 21 days (Fig. 2). The very low percentage of bait holes totally or partially pierced in the Mix treatment $(1.0 \pm 1.8 \%$ of organic matter loss) showed no significant influence of abiotic processes (e.g., physical or chemical constraints that may lead to the dissolution or the detachment of the substrates) in the degradation of bait-lamina in the sediment compartment of the laboratory channels, confirming our previous observation on sterile sediments from a preliminary (unpublished) experiment. Taken together, these results showed that the bait-lamina method can be used to measure the breakdown and decomposition activities of particulate organic matter by sediment communities (i.e., microorganisms and macro-invertebrates $<2 \mathrm{~mm}$ here).

Fig. 2. Mean mass loss (percentage of the initial mass) measured at day 21 with the bait-lamina test $(n=3 \pm S D)$ in the four treatments (5 replicates per sample). Different letters indicate significant betweentreatment differences in baitlamina mass loss (Tukey test, $\mathrm{p}<0.05)$..

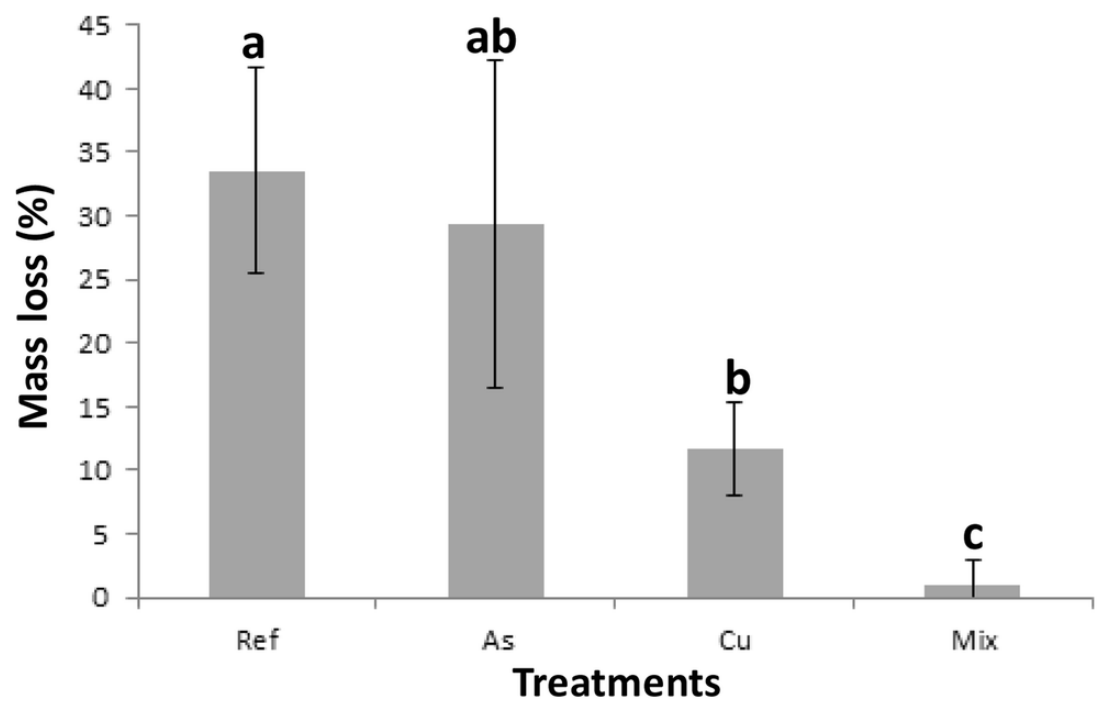


We also assessed the feasibility and relevance of using bait-lamina as an integrative ecotoxicological indicator of the functional impacts of $\mathrm{Cu}$ and $\mathrm{As}$, alone or in mixture, on sediment communities. In our experimental conditions, bait-lamina organic matter loss was not significantly reduced in the As-spiked sediment $(29.4 \pm 12.9 \%)$ but was significantly decreased in the Cu-spiked sediment $(11.6 \pm 3.7 \%$, $\mathrm{p}=0.05$ ) compared to the reference channels (but without significant difference between As and $\mathrm{Cu}$ treatments, $p=0.12$ ). When both metals were co-present in mixture, the bait-lamina organic matter loss was almost totally inhibited $(1.0 \pm 1.8 \%)$, with a significantly higher combined effect than the effect of Cu alone $(p=0.04)$.

Whereas bait-lamina probably did not undergo abiotic degradation, the artificial tablets buried in the autoclaved sediment showed a weight loss of $15.8 \pm 1.7 \%$ (data not shown). This result points to the possible occurrence of abiotic degradation processes and/or of decomposition activities performed by persistent microorganisms despite autoclaving. Based on use of the tablets, the consumption of organic matter was thus assessed by considering normalized values, obtained by subtracting the mean tablet degradation percentage observed in the autoclaved sediment (Fig. 3).

Fig. 3. Mean normalized mass loss (normalized percentage of the initial mass) measured at day 21 with the tablets $(n=3 \pm S D)$ in the four treatments (5 replicates per sample). Values were normalized by subtracting mean mass loss observed in sterile sediment (horizontal lines give $95 \%$ confidence intervals for mean tablet degradation percentage).

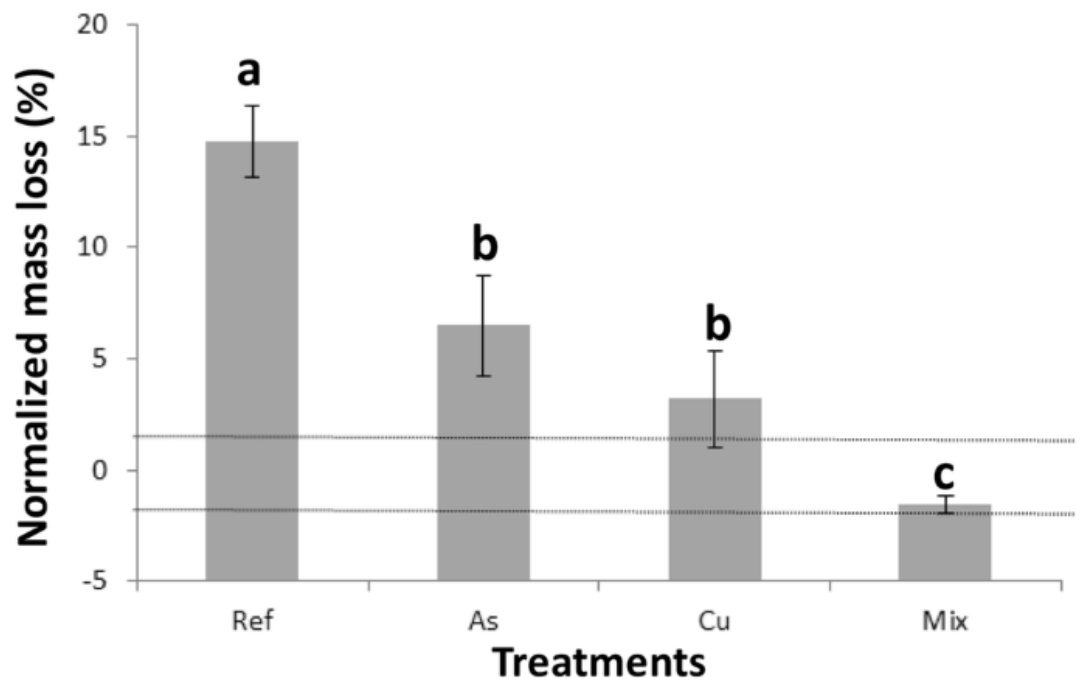

In the reference uncontaminated sediments, tablet degradation was $14.7 \pm 1.6 \%$ higher than the mean abiotic degradation observed in sterile sediments, thus confirming the relevance of this kind of artificial substrate for estimating the consumption of organic matter by sediment communities. Compared to the reference channels, both $A s(p<0.01)$ and $\mathrm{Cu}(p<0.001)$ treatments significantly inhibited the tablet organic matter loss, without significant difference between the two metals $(p=0.23)$. As observed with bait lamina, the inhibition in tablet organic matter loss was almost total when $\mathrm{Cu}$ and As were combined, and the Mix treatment was significantly different from the $A s(p<0.01)$ and $\mathrm{Cu}$ $(p=0.03)$ treatments alone.

The effects of spiked metals on natural sediment communities were evidenced with both bait lamina and artificial tablets, both of which have the advantages of being relatively inexpensive, simple to prepare, and easy to use. However, and contrary to the bait-lamina method, the tested tablets were significantly degraded by abiotic factors, as shown by the roughly $15 \%$ weight loss observed in the sterile sediment. This emphasizes the need to use controls in experimental studies and suggests possible limitations when comparing organic matter breakdown and decomposition activities of communities from sediments characterized by different abiotic properties, especially during in situ surveys. 
Whatever the substrate used (i.e., bait lamina or tablets), Cu had a significant effect on organic matter loss. This result contradicts findings from previous mesocosm studies (Gardham et al., 2015; Sutcliffe et al., 2019), which showed no effect of sediment Cu contamination (from 46 to $650 \mathrm{mg} \mathrm{kg}-1$ ) on the consumption of organic matter, whatever the kind of substrate tested (i.e., leaf litter, cotton strip, or cellulose paper). Differences between the present results and those of Gardham et al. (2015) and Sutcliffe et al. (2019) could be due to methodological differences including the particulate organic matter substrates used, exposure time and substrates deployment. Indeed, most of the substrates used in the previous studies were left on the surface, except for some leaf litterbags that were buried in the sediment in Gardham et al. (2015). Moreover, it cannot be excluded that the Cu toxicity we reported on organic matter consumption in the contaminated sediments was mainly due to the high quantity of $\mathrm{Cu}$ released from the sediment particulate fraction to the pore water. As mentioned above to explain the high $\mathrm{Cu}$ toxicity we observed with the ostracod test, the strong $\mathrm{Cu}$ effect on organic matter consumption also points to a very high bioavailability of $\mathrm{Cu}$ in our exposure conditions. While Gardham et al. (2015) observed Cu concentrations close to 5 and $3 \mu \mathrm{g} / \mathrm{L}$ in pore water and overlying water respectively, in the present study $\mathrm{Cu}$ concentrations in the surface water were much higher and varied from $60.1 \pm 5.4 \mu \mathrm{g} \mathrm{L}-1$ at day 0 to $38.9 \pm 0.7 \mu \mathrm{g}-1$ at day 21 (Table 2).

In contrast, the effect of As applied alone was moderate in comparison to $\mathrm{Cu}$ despite concentrations of As in the overlying water ranging between 760 and $2829 \mu \mathrm{g} L-1$ depending on the sampling time (Table 2). This effect was only significant on tablet organic matter loss, and not on the bait-lamina. The apparent difference in the sensitivity of the two methods to the As toxicity was probably due in part to the higher between-replicate variability observed with the bait-lamina method. This may be also partially attributable to the lack of sensitivity of the method used to interpret the results, which is only based on three classes defined according to visual analysis of the holes (i.e., not pierced, partially pierced, or totally pierced) and/or to the surface area-to-volume ratio differences in the two tools (i.e., the bait-lamina method has two exposed sides while the tablet is fully exposed). Given this methodological limitation, the tablet method, which is based on weight loss measurement, is arguably more sensitive for assessing low or moderate effects on the consumption of particulate organic matter.

Whatever the method used, the toxicity induced by the mixture of $\mathrm{Cu}$ and $\mathrm{As}$ was higher than expected by a simple additive effect, leading to an almost total inhibition of the organic matter consumption in mixture-exposed sediments. Co-occurrence of different metals in aquatic ecosystems is frequent (Altenburger, 2011) and previous studies have reported sediment and particulate contamination by metal mixtures including $\mathrm{Cu}$ and As (Rabiet et al., 2015; De Castro-Català et al., 2016). However, knowledge of the ecotoxicological effects of such joint exposure in sediment is still scarce (De CastroCatalà et al., 2016; Mahamoud Ahmed et al., 2018). Assessing the toxicity of river sediments contaminated by chemical mixtures (including metals and pesticides), De Castro-Català et al. (2016) showed that $\mathrm{Cu}$ was one of the main contributors of the effects they observed from ecotoxicity bioassays and from the description of the natural invertebrate communities. In a previous study (Mahamoud Ahmed et al., 2018), we demonstrated that the effects of the mixture described in the present study on selected microbial activities were similar or slightly stronger than the effects of $\mathrm{Cu}$ alone. Moreover, the possible combined effects were not reflected in the bacterial community structure, which was similar in sediments exposed to $\mathrm{Cu}$ alone or to the mixture of $\mathrm{Cu}$ and As (Mahamoud Ahmed et al., 2018). These results suggest that the interaction between $\mathrm{Cu}$ and As had limited effects on the microbial functional potential while not modifying the community structure. The two methods tested in the present study, which allow the assessment of ecotoxicological effects on the effective activity of the sediment microbial and invertebrate communities in terms of organic matter breakdown and decomposition, were thus more sensitive to detect the combined effects of $\mathrm{Cu}$ 
and As than the assessment of the microbial functional potential. This can be due, at least partially, to the fact that As alone had no effect on the sediment bacterial structure and on the microbial functional potential (Mahamoud Ahmed et al., 2018) while it inhibited the consumption of particulate organic matter as shown from the use of the tablets in the present study (Fig. 3). It could suggest that As toxicity in the tested exposure conditions mainly affect invertebrates, thus confirming the necessity for developing ecotoxicological studies with organisms from different organizational levels to consider different sensitivities to contaminants, according among others, to their mode of action (De CastroCatalà et al., 2016).

\section{How can artificial organic matter substrates improve the ecological relevance of sediment environmental risk assessment?}

The use of artificial organic matter substrates offers a cheap and easy approach (Bart et al., 2018) that can help improve the ecological relevance of sediment environmental risk assessment for several reasons. First, it enables functional ecotoxicological assessment to be performed at the benthic community level, which is the intermediate biological level between populations and ecosystems. Moreover, it enables investigations of ecotoxicological effects on an important ecological function (i.e., particulate organic matter breakdown and decomposition) involving different microorganisms (mainly hyphomycete fungi and heterotrophic bacteria) and macroorganisms. In microbial ecotoxicology (Ghiglione et al., 2016), the functional endpoints investigated to assess sediment heterotrophic community response to contaminants include, among others, various enzymatic activities, basal or substrate-induced respiration, and metabolic activities related to the nitrogen cycle, such as denitrification (e.g., Widenfalk et al., 2004; Zoppini et al., 2016, Jaiswal and Pandey, 2018; Mahamoud Ahmed et al., 2018). However, these approaches are based on measurements of functional potential, which are performed under optimized laboratory conditions and so do not necessarily reflect the effective activity of these communities in the real-world environment. In comparison, direct study of organic matter breakdown and decomposition processes in sediments via the use of bait lamina or artificial tablets can give relevant information on the ecotoxicological risks and effects on this crucial ecosystem process. This kind of approach could thus be viewed as a powerful tool for developing predictive functional ecotoxicology in the sediment compartment, by considering the ecological role of both microorganisms and benthic invertebrates as consumers of organic matter. Reaching further forward, it should be possible to dissociate microbial-driven decomposition from invertebrate feeding, for example by enclosing the tablets in small-mesh-size bags (barring access to invertebrates) and large-mesh-size bags (giving access to invertebrates), as frequently used in studies assessing leaf-litter breakdown (Brosed et al., 2016; Rossi et al., 2017, 2019). Finally, the methods tested here could be proposed for standardization to further improve sediment ERA protocol, as already done in the soil compartment through the TRIAD approach (ISO 19204, 2017).

\section{Conclusions}

The two methods tested allowed the assessment of functional impacts of metal exposure in the sediment through the study of particulate organic matter consumption by benthic microorganisms and invertebrates. Both methods are inexpensive and easy to handle, and they carry both advantages and limits. Indeed, the bait-lamina method offers the main advantages of not being subjected to abiotic degradation in sediments and of being a standardized method that is already used for the assessment of the biological status of soils (ISO 18311, 2016) and for environmental risk assessment of soil contamination (ISO 19204, 2017). However, the current interpretation method, which is based only on 
a simple definition of three classes according to visual analysis of the holes, is arguably not sensitive enough to detect low or moderate ecotoxicological effects or to specifically assess effects on microbial decomposition. In contrast, the observed abiotic degradation of the artificial tablets used in the present study highlights the need for reference controls, which points to possible limitations when comparing sediments characterized by different abiotic properties. That said, the artificial tablet substrate method, which is based on weight loss measurement, may be more relevant for assessing low or moderate effects on feeding activities and for specifically focusing on microbial decomposition if the tablets can be isolated in small-mesh-size bags barring access to invertebrates.

In summary, the proposed methods offer potentially powerful tools for developing functional ecotoxicology in the sediment compartment by considering the ecological role of both microorganisms and macroinvertebrates as consumers of organic matter. Note too that such a simple tool could be applicable in both soil and sediment ecotoxicology, opening interesting perspectives for ecotoxicological studies to better integrate the soil-sediment-water continuum.

\section{References}

Altenburger R (2011) Understanding combined effects for metal co-exposure in ecotoxicology. Met lons Life Sci 8:1-26

Ancion PY, Lear G, Dopheide A, Lewis GD (2013) Metal concentrations in stream biofilm and sediments and their potential to explain biofilm microbial community structure. Environ Pollut 173:117-124

Andre A, Antunes SC, Gonçalves F, Pereira R (2009) Bait-lamina assay as a tool to assess the effects of metal contamination in the feeding activity of soil invertebrates within a uranium mine area. Environ Pollut 157:2368-2377

Bart S, Roudine S, Amossé J, Mougin C, Péry ARR, Pelosi C (2018) How to assess the feeding activity in ecotoxicological laboratory tests using enchytraeids? Environ Sci Pollut Res 25:33844-33848

Brosed M, Lamothe S, Chauvet E (2016) Litter breakdown for ecosystem integrity assessment also applies to streams affected by pesticides. Hydrobiologia 773:87-102

Burton GA (2013) Assessing sediment toxicity: past, present, and future. Environ. Toxicol Chem 32:14381440

Casabe N, Piola L, Fuchs J, Oneto ML, Pamparato L, Basack S, Gimenez R, Massaro R, Papa JC, Kesten E (2007) Ecotoxicological assessment of the effects of glyphosate and chlorpyrifos in an Argentine soya field. J Soils Sediments 7:232-239

Chapman PM (1990) The sediment quality triad approach to determining pollution-induced degradation. Sci Total Environ 97(98):815-825

Clements (1999) Metal tolerance and predator-prey interactions in benthic macroinvertebrate stream communities. Ecol Appl 9:1073-1084

Dabrin A, Durand CL, Garric J, Geffard O, Ferrari BJD, Coquery M (2012) Coupling geochemical and biological approaches to assess the availability of cadmium in freshwater sediment. Sci Total Environ 424:308-315

De Castro-Català N, Kuzmanovic M, Roig N, Sierra J, Ginebreda A, Barceló D, Pérez S, Petrovic M, Picó Y, Schuhmacher M, Muñoz I (2016) Ecotoxicity of sediments in rivers: invertebrate community, toxicity bioassays and the toxic unit approach as complementary assessment tools. Sci Total Environ 540:297306

DREAL-REMIPP (2013) Micropolluants dans les sédiments de la région Rhône-Alpes. Données cours d'eau et plans d'eau 2006-2011. ISBN: 978-2-11-129823-1. $84 p$

Farag AM, Nimick DA, Kimball BA, Church SE, Harper DD, Brumbaugh WG (2007) Concentrations of metals in water, sediment, biofilm, benthic macroinvertebrates, and fish in the Boulder River watershed, Montana, and the role of colloids in metal uptake. Arch Environ Contam Toxicol 52:397-409

Farag AM, Woodward DF, Goldstein JN, Brumbaugh W, Meyer JS (1998) Concentrations of metals associated with mining waste in sediments, biofilm, benthic macroinvertebrates, and fish from the Coeur d'Alene River Basin, Idaho. Arch Environ Contam Toxicol 34:119-127

Faupel M, Ristau K, Traunspurger W (2012) The functional response of a freshwater benthic community to cadmium pollution. Environ Pollut 162:104-109 
Filzek PDB, Spurgeon DJ, Broll G, Svendsen C, Hankard PK, Parekh N, Stubberud HE, Weeks JM (2004) Metal effects on soil invertebrate feeding: measurements using the bait lamina method. Ecotoxicology 13:807-816

Gardham S, Chariton AA, Hose GC (2015) Direct and indirect effects of copper contaminated sediments on the functions of model freshwater ecosystems. Ecotoxicology 24:61-70

Ghiglione JF, Martin-Laurent F, Pesce S (2016) Microbial ecotoxicology: an emerging discipline facing contemporary environmental threats. Environ Sci Pollut Res 23:3981-3983

Griffiths BS, Römbke J, Schmelz RM, Scheffczyk A, Faber JH, Bloem J, Peres G, Cluzeau D, Chabbi A, Suhadolc M, Sousa JP, Martins da Silva P, Carvalho F, Mendes S, Morais P, Francisco R, Pereira C, Bonkowski M, Geisen S, Bardgett RD, Vries FT, Bolger T, Dirilgen T, Schmidt O, Winding A, Hendriksen NB, Johansen A, Philippot L, Plassart P, Bru D, Thomson B, Griffiths RI, Bailey MJ, Keith A, Rutgers M, Mulder C, Hannula SE, Creamer R, Stone D (2016) Selecting cost effective and policy-relevant biological indicators for European monitoring of soil biodiversity and ecosystem function. Ecol Indic 69:213-223

Höss S, Claus E, Von der Ohe PC, Brinke M, Gude H, Heininger P, Traunspurger W (2011) Nematode species at risk - a metric to assess pollution in soft sediments of freshwaters. Environ Pollut 37:940-949

INERIS (2010). Qualité chimique des sédiments fluviaux en France. Synthèse des bases de données disponibles. Rapport d'étude. N INERIS-DRC-10-105335-04971A. $99 \mathrm{p}$

ISO 14371 (2012) Water quality-determination of freshwater sediment toxicity to Heterocypris incongruens. Crustacea, Ostracoda, $24 \mathrm{p}$

ISO 18311, 2016. Soil quality-method for testing effects of soil contaminants on the feeding activity of soil dwelling organisms - bait-lamina test, $16 \mathrm{p}$

ISO 19204, 2017. Soil quality-procedure for site-specific ecological risk assessment of soil contamination (soil quality TRIAD approach), $28 \mathrm{p}$

Jaiswal D, Pandey J (2018) Impact of heavy metal on activity of some microbial enzymes in the riverbed sediments: ecotoxicological implications in the Ganga River (India). Ecotoxicol Environ Saf 150:104-115

Jensen J, Mesman M (2006) Ecological risk assessment of contaminated land-decision support for site specific investigations. RIVM Report:711701047, $136 \mathrm{p}$

Kampfraath AA, Hunting ER, Mulder C, Breure AM, Gessner MO, Kraak MHS, Admiraal W (2012) DECOTAB: a multipurpose standard substrate to assess effects of litter quality on microbial decomposition and invertebrate consumption. Freshwater Sci 31:1156-1162

Kohušová K, Havel L, Vlasák P, Tonika J (2011) A long-term survey of heavy metals and specific organic compounds in biofilms, sediments and surface water in a heavily affected river in the Czech Republic. Environ Monit Assess 174:555-572

Kratz W (1998) The bait-lamina test. Environ Sci Pollut Res 5:94-96

Kudlak B, Wolska L, Namiesnik J (2011) Determination of EC50 toxicity data of selected heavy metals toward Heterocypris incongruens and their comparison to "direct-contact" and microbiotests. Environ Monit Assess 174:509-516

MacDonald DD, Ingersoll CG, Berger TA (2000) Development and evaluation of consensus-based sediment quality guidelines for freshwater ecosystems. Arch Environ Contam Toxicol 39:20-31

Mahamoud Ahmed A, Lyautey E, Bonnineau C, Dabrin A, Pesce S (2018) Environmental concentration of copper, alone or in mixture with arsenic, can impact river sediment microbial community structure and functions. Front Microbiol 9:1852

Niemeyer JC, Nogueira MA, Carvalho GM, Cohin-De-Pinho SJ, Outeiro US, Rodrigues GG, da Silva EM, Sousa JP (2012) Functional and structural parameters to assess the ecological status of a metal contaminated area in the tropics. Ecotoxicol Environ Saf 86:188-197

Niemeyer JC, de Santo FB, Guerra N, Ricardo Filho AM, Pech TM (2018) Do recommended doses of glyphosate-based herbicides affect soil invertebrates? Field and laboratory screening tests to risk assessment. Chemosphere 198:154-160

Pesce S, Perceval O, Bonnineau C, Casado-Martinez C, Dabrin A, Lyautey E, Naffrechoux E, Ferrari BJD (2018) Looking at biological community level to improve ecotoxicological assessment of freshwater sediments: report on a first French-Swiss workshop. Environ Sci Pollut Res 25:970-974

Piscart C, Navel S, Maazouzi C, Montuelle B, Cornut J, Mermillod-Blondin F, des Châtelliers MC, Simon L, Marmonier $P$ (2011) Leaf litter recycling in benthic and hyporheic layers in agricultural streams with different types of land use. Sci Total Environ 409:4373-4380

Posthuma L, van Straalen NM (1993) Heavy-metal adaptation in terrestrial invertebrates: a review of occurrence, genetics, physiology and ecological consequences. Comp Biochem Physiol 106:11-38 
Rabiet M, Coquery M, Carluer N, Gahou J, Gouy V (2015) Transfer of metal(loid)s in a small vineyard catchment: contribution of dissolved and particulate fractions in river for contrasted hydrological conditions. Environ Sci Pollut Res 22:19224-19239

Rossi F, Artigas J, Mallet C (2017) Structural and functional responses of leaf-associated fungal communities to chemical pollution in streams. Freshw Biol 62:1207-1219

Rossi F, Mallet C, Portelli C, Donnadieu F, Bonnemoy F, Artigas J (2019) Stimulation or inhibition: leaf microbial decomposition in streams subjected to complex chemical contamination. Sci Total Environ 648:1371-1383

Sevilla JB, Nakajima F, Kasuga I (2014) Comparison of aquatic and dietary exposure of heavy metals Cd, Cu, and $\mathrm{Zn}$ to benthic ostracod Heterocypris incongruens. Environ Toxicol Chem 33:1624-1630

Sutcliffe B, Chariton AA, Harford AJ, Hose GC, Greenfield P, Midgley DJ, Paulsen IT (2018) Diverse fungal lineages in subtropical ponds are altered by sediment-bound copper. Fungal Ecol 34:28-42

Sutcliffe B, Hose GC, Harford AJ, Midgley DJ, Greenfield P, Paulsen IT, Chariton AA (2019) Microbial communities are sensitive indicators for freshwater sediment copper contamination. Environ Pollut 247:1028-1038

Tlili A, Marechal M, Montuelle B, Volat B, Dorigo U, Bérard A (2011) Use of the MicroResp ${ }^{\mathrm{TM}}$ method to assess pollution-induced community tolerance to metals for lotic biofilms. Environ Pollut 159:18-24

Torokne A, Toro K (2010) Evaluation of the toxicity of river and creek sediments in Hungary with two different methods. Environ Toxicol 25:504-509

Vignati DAL, Ferrari BJD, Dominik J (2007) Laboratory-to-field extrapolation in aquatic sciences: conceptual frameworks are needed to narrow the gap between laboratory- and field-based research. Environ Sci Technol 41:1067-1073

Von Törne E (1990) Assessing feeding activities of soil living animals. I. Bait lamina tests. Pedobiologia 34:89-101

Welsch J, Songling C, Buckley HL, Lehto NJ, Jones EE, Case BS (2019) How many samples? Soil variability affects confidence in the use of common agroecosystem soil indicators. Ecol Indic 102:401-409

Widenfalk A, Svensson JM, Goedkoop W (2004) Effects of the pesticides captan, deltamethrin, isoproturon, and pirimicarb on the microbial community of a freshwater sediment. Environ Toxicol Chem 23:19201927

Yandell BS (1997) Practical data analysis for designed experiments (Crc Press)

Young RG, Matthaei CD, Townsend CR (2008) Organic matter breakdown and ecosystem metabolism: functional indicators for assessing river ecosystem health. J North Am Benthol Soc 27:605-625

Zoppini A, Marxsen J (2011) Importance of extracellular enzymes for biogeochemical processes in temporary river sediments during fluctuating dry-wet conditions. In: Shukla G, Varma A (eds) Soil enzymology. Springer-Verlag, Berlin, pp 103-117

Zoppini A, Ademollo N, Amalfitano S, Capri S, Casella P, Fazi S, Marxsen J, Patrolecco L (2016) Microbial responses to polycyclic aromatic hydrocarbon contamination in temporary river sediments: experimental insights. Sci Total Environ 541:1364-1371

\section{Acknowledgments}

The authors thank Bernadette Volat, Josiane Gahou, Bernard Motte and Christophe Rosy for their valuable technical support.

\section{Funding}

This work was funded by a grant from the Auvergne-Rhône-Alpes regional council (a Coopera grant for research and an Explora Pro grant for mobility awarded to Stéphane Pesce at the Ecotox Centre in Lausanne). 